Mariusz Zięba

Instytut Psychologii, Wydział

Zamiejscowy w Poznaniu

Szkoła Wyższa Psychologii Społecznej

Mateusz Zatorski

Wydział Psychologii, Szkoła Wyższa

Psychologii Społecznej, Warszawa
Psychologia Jakości Życia

Psychology of Quality of Life

2013, tom 12, nг 2 (167-182)

DOI: $10.5604 / 16441796.1090794$

\title{
Narracje oraz nadzieja podstawowa a wzrost potraumatyczny po przeszczepieniu nerki
}

\begin{abstract}
Przewlekła choroba niewydolności nerek oraz operacja przeszczepu nerki to wydarzenie życiowe wiążące się z wieloma poważnymi konsekwencjami, znacząco wpływające na związaną ze zdrowiem jakość życia, ale również mogące prowadzić do wzrostu potraumatycznego. $W$ artykule prezentujemy badanie 51 pacjentów po przeszczepie nerki. W I etapie badania, 4 tygodnie po przeszczepie, mierzono poziom nadziei podstawowej (BHI-R), nadziei na sukces (KNS), samooceny (SES) i refleksyjności (LMS) oraz przeprowadzano wywiad narracyjny. 10-12 miesięcy później dokonywano pomiaru wzrostu potraumatycznego (SRGS). Wyniki badania wskazują na to, że doświadczeniu przez pacjentów wzrostu potraumatycznego po upływie roku od przeszczepu nerki sprzyja wysoki początkowy poziom nadziei podstawowej. Pozytywną rolę pełni też tendencja do konstruowania reprezentacji poznawczej swoich doświadczeń w formie wewnętrznie spójnej narracji.
\end{abstract}

Słowa kluczowe: wzrost potraumatyczny, nadzieja podstawowa, narracje, przeszczep, psychologia zdrowia

Adres do korespondencji: Mariusz Zięba, Szkoła Wyższa Psychologii Społecznej, Wydział Zamiejscowy w Poznaniu, ul. gen. Tadeusza Kutrzeby 10, 61-719 Poznań, e-mail: mariusz.zieba@swps. edu.pl

Przygotowanie artykułu sfinansowane ze środków budżetowych na naukę w latach 2010-2013 w ramach projektu badawczego N N106 281739. 


\section{Wprowadzenie}

\section{Choroba somatyczna i wzrost potraumatyczny}

Choroby i problemy zdrowotne powodują zazwyczaj znaczące pogorszenie jakości życia, gdyż wiążą się z ograniczeniem możliwości funkcjonalnych człowieka, obniżeniem samopoczucia i spostrzeganego zadowolenia z życia, a także wynikającym z procesów chorobowych pogorszeniem kondycji fizycznej (Tobiasz-Adamczyk, 1998). Istotnym elementem doświadczania choroby jest też często ból i cierpienie (Heszen i Sęk, 2007; Ogińska-Bulik i Juczyński, 2008). Współcześnie w psychologii zdrowia zwraca się również uwagę na korzyści, jakie może przynosić choroba. Heszen i Sęk (2007) jako przykłady wtórnych zysków z choroby podają zainteresowanie ze strony otoczenia i ulgi, np. zwolnienie z nielubianych obowiązków. Wśród pozytywnych konsekwencji choroby można też jednak wymienić zmiany w zakresie przekonań, postaw i zachowań (np. zdrowotnych), będące skutkiem doświadczenia choroby.

Wyniki coraz większej ilości współczesnych badań wskazują na to, że proces radzenia sobie z traumatycznym lub krytycznym wydarzeniem życiowym może prowadzić do znaczącej pozytywnej transformacji osobowości (Linley i Joseph, 2004; Tedeschi i Calhoun, 2012). Wzrost potraumatyczny obejmuje zmiany fundamentalnych przekonań na temat samego siebie i świata w takich obszarach, jak: wzrost poczucia osobistej siły, odkrycie radości życia oraz znaczenia relacji z innymi ludźmi czy też rozwój duchowy (Calhoun i Tedeschi, 2006, 2013; Ogińska-Bulik i Juczyński, 2010; Ogińska-Bulik, 2013). Takie pozytywne zmiany obserwowane byly $w$ badaniach empirycznych nie tylko $w$ przypadku zdarzeń traumatycznych, ale również w kontekście różnego rodzaju chorób, zarówno tych o krótszym czasie trwania, jak i przewlekłych (Park, 2009). Stosunkowo najwięcej badań dotyczących wzrostu potraumatycznego doświadczanego $w$ rezultacie choroby i radzenia sobie z jej konsekwencjami przeprowadzono wśród pacjentów onkologicznych (por. przegląd badań Stanton, Bower i Low, 2006). Pozytywne zmiany osobowości będące rezultatem adaptacji do choroby stwierdzano jednak również w przypadku pacjentów cierpiących na wiele innych chorób somatycznych, takich jak AIDS, choroby autoimmunologiczne, cukrzyca, artretyzm, łuszczyca itd. (Park, 2009).

Choroby różnią się między sobą na wiele sposobów. Park (2009) wśród najistotniejszych z puntu widzenia przebiegu i rezultatu procesu wzrostu potraumatycznego obszarów różnic wymienia m.in.: moment pojawienia się objawów choroby (nagłe i niespodziewane vs. stopniowo narastające), jej genezę (znana przyczyna, np. genetyczna, lub też nieznana; pozostająca pod kontrolą pacjenta lub też nie), wpływ na codzienne funkcjonowanie, perspektywy wyleczenia (śmierci). Zdaniem Park wszelkie generalizacje dotyczące tego, czy i w jakim zakresie choroba może przynieść pozytywne skutki, a wśród nich wzrost potraumatyczny, są nieuprawnione, gdyż wziąć pod uwagę trzeba specyfikę choroby. 
Oceniana z tej perspektywy sytuacja pacjentów, którym przeszczepiono nerkę. jest bardzo złożona. Pacjenci ci to w większości osoby podlegające przed przeszczepem długiemu okresowi dializ, które są jedyną moźliwą odpowiedzią terapeutyczną na skrajną niewydolność nerek. Przeszczep jest zatem kolejnym etapem leczenia długotrwałej choroby, stopniowo coraz bardziej ograniczającej moźliwości funkcjonowania człowieka. Z jednej strony udany przeszczep daje nową nadzieję na odzyskanie zdrowia, a także istotne polepszenie warunków życia wynikające z zaprzestania uciążliwych dializ. Z drugiej zaś strony sama operacja i związane z nią ryzyko poważnych powikłań, a nawet śmierci, jest źródłem silnego stresu. Kwalifikacja do operacji zwykle poprzedzona jest długim okresem oczekiwania na dawcę organu i koniecznością ciągłej gotowości do natychmiastowego wyjazdu do szpitala, co pogłębia odczucie niepewności i nieprzewidywalności towarzyszące tej sytuacji.

\section{Rola przekonań w procesie wzrostu potraumatycznego}

Wśród czynników indywidualnych pełniących rolę moderatorów wzrostu potraumatycznego szczególnie ważną rolę odgrywają takie cechy osobowości, jak nadzieja i optymizm (Tennen i Affleck, 1998) oraz nadzieja podstawowa (Trzebiński i Zięba, 2012; Zięba, Czarnecka-van Luijken i Wawrzyniak, 2010), a także rodzaj procesów poznawczych zaangażowanych $w$ budowanie reprezentacji poznawczej wydarzenia traumatycznego i jego konsekwencji dla życia człowieka (Calhoun i Tedeschi, 2006; Janoff-Bulman, 2006; Payne, Joseph i Tudway, 2007).

Różnego rodzaju traumatyczne i krytyczne wydarzenia oraz poważne zmiany życiowe wywierają znaczący wpływ na sposób myślenia jednostki o samej sobie i otaczającej ją rzeczywistości. Według Janoff-Bulman (1992, 2006) jedną z ważnych konsekwencji traumy jest podważenie dotychczasowych fundamentalnych schematów czy też założeń (assumptions) stanowiących podstawę formułowania reprezentacji poznawczych rzeczywistości, w jakiej znajduje się człowiek, oraz oczekiwań na temat przyszłych konsekwencji jego działań. Globalne przekonania na temat samego siebie i świata, takie jak optymizm i nadzieja, wpływają na konstruowane przez człowieka poznawcze reprezentacje rzeczywistości i są ważnym elementem systemu regulacji obejmującego procesy poznawcze, afektywne i tendencje behawioralne (Mischel i Shoda, 2008).

C.R. Snyder przedstawił koncepcję nadziei na sukces rozumianej jako pozytywny stan motywacyjny, oparty na powiązanych ze sobą wzajemnie dwu rodzajach przekonań. Pierwszym $\mathrm{z}$ nich jest przekonanie o moźliwości zrealizowania powziętego planu - przekonanie o posiadaniu silnej woli. Drugi komponent nadziei dotyczy postrzegania siebie jako osoby zdolnej i zaradnej, a przez to będącej w stanie wymyślić lub poznać jeden lub więcej skutecznych sposobów prowadzących do osiągnięcia celu - umiejętność znajdowania rozwiązań (Snyder, Cheavans i Michael, 1999). Nadzieja na sukces, podobnie 
jak optymizm, wiąże się z oczekiwaniem pozytywnych zdarzeń w przyszłości, ale oczekiwanie to poparte jest wiarą we wlasne moźliwości działania (Snyder, Sympson, Michael i Cheavens, 2000). Wysoki poziom nadziei na sukces wiąże się z zaangażowaniem we własne cele i jest predyktorem zorientowanych na problem, aktywnych i opartych na planowaniu strategii zmagania się z chorobą nowotworową (Stanton, Danoff-Burg i Huggins, 2002). W sytuacji terminalnej choroby nadzieja na sukces ułatwia formulowanie nowych, adekwatnych do zmienionej w wyniku tego wydarzenia sytuacji celów życiowych oraz ich realizację (Gum i Snyder, 2002).

Odmienne ujęcie nadziei przedstawili Trzebiński i Zięba (2003, 2004). Prezentowana przez nich nadzieja podstawowa oznacza ogólne, zwykle słabo zwerbalizowane przekonania jednostki na temat dwóch cech świata - jego sensowności oraz przychylności wobec ludzi. Przekonania te rzadko są aktywizowane w codziennych sytuacjach i pełnią istotną rolę funkcjonalną przede wszystkim w sytuacjach o szczególnie dużym znaczeniu dla jednostki. Z dotychczasowych badań (Trzebiński i Zięba, 2012; Zięba, Czarnecka-van Luijken i Wawrzyniak, 2010) wiadomo, że nadzieja podstawowa jest dobrym i na ogół lepszym niż optymizm predyktorem wzrostu potraumatycznego w przypadku różnego typu wydarzeń traumatycznych, a także zmagania się z chorobą nowotworową.

Wśród szczególnie ważnych kategorii przekonań wpływających na funkcjonowanie jednostki należy wskazać również samoocenę, czyli uogólnioną pozytywną lub negatywną postawę wobec samego siebie. Osoby o wysokiej samoocenie są bardziej aktywne oraz wytrwałe i postrzegają siebie bardziej pozytywnie $w$ wielu wymiarach funkcjonowania zadaniowego i społecznego (Łaguna, Lachowicz-Tabaczek i Dzwonkowska, 2007).

\section{Zaangażowanie poznawcze i narracyjna strukturalizacja doświadczenia a wzrost potraumatyczny}

Zdaniem Tedeschiego i Calhouna (2004) warunkiem wzrostu potraumatycznego jest zaangażowanie poznawcze, polegające na dokładnej i głębokiej analizie znaczenia wydarzenia traumatycznego dla życia człowieka. Podejmowanie prób przemyślenia swojej obecnej sytuacji, jej przyczyn i konsekwencji, również tych długofalowych, może wiązać się z odczuwaniem napięcia emocjonalnego i obniżeniem samopoczucia. To bolesne niekiedy rozmyślanie może jednak przynieść pozytywne skutki - w rezultacie zaangażowania poznawczego stworzona może zostać nowa, spójna reprezentacja poznawcza sytuacji pacjenta oraz ocena jej znaczenia dla jednostki i jej sposobów rozumienia świata, co prowadzi do wzrostu potraumatycznego.

Ważnym czynnikiem wpływającym na jakość procesów poznawczych jest poziom refleksyjności. Refleksyjność jest stanem poznawczej gotowości i żywej świadomości, charakteryzującym się obecnością czterech aspektów poznawczego funkcjonowania: a) tworzenia nowych kategorii, b) poszukiwania nowych 
informacji, c) otwartości na różne sposoby postrzegania jednego problemu, d) wysokiej percepcji kontekstu zdarzeń i umiejętności wykorzystania informacji w nim zawartych (Langer, 1989). Refleksyjność związana jest z potrzebą ustosunkowywania się do poznawanych informacji, a także twórczego poszukiwania odpowiedzi na bazie własnych doświadczeń, co może być szczególnie ważne w procesie nadawania znaczenia doświadczeniu choroby i zmianom tożsamości będącym konsekwencją przeszczepu.

Zdaniem wielu autorów ludzie poznają i opisują świat oraz własne doświadczenia w formie opowieści (Bruner, 1986, 1991; Gergen i Gergen, 1986; Trzebiński, 2002). Narracje umożliwiają porządkowanie i łączenie w subiektywnie spójne ciągi pojedynczych zdarzeń z życia własnego i innych osób (McAdams, 2001). Narracyjna forma reprezentacji poznawczej zdarzeń, w tym zdarzeń traumatycznych, nie jest jedyną możliwą. Bruner (1986) opisał dwa komplementarne sposoby interpretowania rzeczywistości: myślenie paradygmatyczne, którego specyfiką jęst oddzielanie zdarzeń od ich kontekstu, poszukiwanie ogólnych wzorców i prawidłowości, racjonalne i logiczne łączenie faktów i wyjaśnianie zjawisk oraz przypisywanie zdarzeń do określonych kategorii poznawczych oraz myślenie narracyjne, które prowadzi do tworzenia reprezentacji poznawczej zdarzeń i sytuacji w formie narracji opowiadającej o osobistych przeżyciach bohatera narracji, jego intencjach i stojących na drodze ich realizacji komplikacjach. To, czy w danej sytuacji zaktywizowane zostanie myślenie narracyjne czy też paradygmatyczne, czego konsekwencją będzie m.in. zastosowanie typowych dla danego trybu myślenia sposobów konstruowania reprezentacji poznawczych wydarzenia, zależy od wielu czynników sytuacyjnych (np. wcześniejszej aktywizacji schematów poznawczych skojarzonych z danym trybem myślenia), ale również od indywidualnych właściwości osoby, wśród których należy wyodrębnić kompetencję narracyjną. Jak dowiedli Stemplewska-Żakowicz, Szewczyk, Piotrowska i Wawrzeniecki (2006), ludzie charakteryzują się właściwą dla siebie, względnie stałą i wewnętrznie spójną dyspozycją ujmowania doświadczenia w formę spójnej historii. Poziom kompetencji narracyjnej wpływa na narracyjne strukturalizowanie poszczególnych doświadczeń.

Wielu autorów wskazuje na to, że pozytywną rolę w procesie readaptacji do traumy pełni konstruowanie reprezentacji poznawczej wydarzenia traumatycznego w formie narracji (McAdams, 2013; Neimeeyer, 2006; Pals, 2006; Pennebaker i Seagal, 1999; Smyth, True i Suoto, 2001).

\section{Cele badania}

Celem badania była weryfikacja hipotezy o pozytywnym znaczeniu w procesie wzrostu potraumatycznego:

1) fundamentalnych przekonań na temat samego siebie i świata - nadziei na sukces, nadziei podstawowej, samooceny; 
2) refleksyjności rozumianej jako potrzeba ustosunkowywania się do poznawanych informacji, a także twórczego poszukiwania odpowiedzi na bazie własnych doświadczeń;

3) narracyjnej struktury reprezentacji poznawczej nadawanej doświadczeniom.

Dodatkowym celem była próba uzyskania odpowiedzi na pytanie o to, jakie formalne i treściowe cechy narracji konstruowanych przez ludzi w sytuacji choroby i poważnego zabiegu operacyjnego sprzyjają lepszej adaptacji oraz doświadczeniu wzrostu potraumatycznego.

\section{Metoda}

\section{Grupa i procedura badania}

Uczestnikami badania było 51 pacjentów (37 mężczyzn) po przeszczepieniu nerki w wieku od 19 do 70 lat $(M=45,57 ; S D=14,97)$. Badanie przeprowadzono na terenie Poradni Nefrologicznej i Transplantacyjnej Szpitala Klinicznego Dzieciątka Jezus w Warszawie. Przeprowadzono dwa spotkania indywidualne z kazdym z badanych: w okresie do 4 tygodni po przeszczepie (I pomiar) i 10-12 miesięcy później. Spotkania odbywały się przy okazji wizyt kontrolnych w Poradni. W drugim spotkaniu wzięło udział tylko 35 pacjentów. Najczęstszym powodem ubytku osób badanych była zmiana miejsca opieki potransplantacyjnej (poradni). Między osobami, które wzięły udział w obydwu etapach badania, i pozostałymi nie było istotnych różnic w zakresie zmiennych wyjaśniających. Spotkanie prowadził doświadczony psycholog z kilkunastoletnią praktyką kliniczną, przeszkolony do przeprowadzania wywiadów zgodnie z podejściem narracyjnym, przy przyjęciu postawy słuchacza opowieści, której autorem jest osoba badana. Przebieg obydwu spotkań był podobny i obejmował dwie części: wywiad narracyjny oraz wypełnienie kwestionariuszy BHI-R, KNS, SES i LMS, a na koniec drugiego spotkania również SRGS.

\section{Narzędzia}

Wvwiad narracvinv. Wywiad narracyjny prowadzony był w oparciu o procedurę Wywiadu Biograficznego McAdamsa w adaptacji Magdaleny Budziszewskiej ( $w$ druku). Ze względu na to, by nie obciążać nadmiernie badanych pacjentów, ograniczono liczbę opowiadanych epizodów do trzech. W trakcie I spotkania prosiliśmy uczestników badania o opowiedzenie dwóch dowolnie przez siebie wybranych ważnych wydarzeń z ich życia, przy czym pierwsze $\mathrm{z}$ nich miało mieć miejsce $\mathrm{w}$ okresie dorosłego życia, ale dawniej niż rok temu, drugie zaś wydarzenie miało pochodzić z ostatniego roku, czyli w okresie oczekiwania na przeszczep. W ostatniej części wywiadu proszono osoby badane o opowiedzenie tego, jak wyobrażają sobie swoją przyszłość i jakie wiążą z nią plany i marzenia. 
Kodowanie danvch z wywiadów narracvjnych. Wypowiedzi pacjentów były nagrywane, na co uzyskano ich pisemną zgodę. Następnie dokonano transkrypcji treści wywiadów i ich analizy. Analiza przeprowadzona była niezależnie przez 2 sędziów kompetentnych, którymi byli psycholodzy. Rezultatem oceny było określenie stopnia narracyjności wypowiedzi oraz obecności w treści narracji wspólnych dla osób badanych tematów i motywów.

Narracyjność wypowiedzi osoby badanej odnosi się do stopnia narracyjnej strukturalizacji reprezentacji poznawczej wydarzenia (epizodu) lub sytuacji, której dotyczy ta wypowiedź. W badaniu przyjęto następującą operacjonalizację narracyjności: strukturę narracji posiada spójna wewnętrznie opowieść o losach konkretnego bohatera, posiadającego określone intencje. Taka definicja narracyjności powstała w oparciu o prace Pennebakera i współpracowników (Pennebaker i Seagal, 1999), którzy oceniali narracyjność tekstu w oparciu o bardzo ogólnie sformułowane kryterium spójności („dobra narracja to taka, która ma jasno zaznaczony początek, rozwinięcie i zakończenie"), oraz Trzebińskiego, który twierdzi, iż „narracja opisuje bohatera z określonymi intencjami, który napotyka trudności w ich realizacji, a trudności te - w wyniku zdarzeń toczących się wokół zagrożonych intencji - zostają bądź nie zostają przezwyciężone" (Trzebiński, 2002, s. 14).

Wypowiedzi wszystkich osób badanych były oceniane pod względem narracyjności ich struktury na 5-stopniowej skali, odrębnie dla trzech kryteriów narracyjności.

\section{a) Wyrazistość bohatera}

1. bohater nie został przedstawiony w wypowiedzi bądź nie wiadomo, która postać spośród przedstawionych jest głównym bohaterem,

2-4. stopnie pośrednie,

5. bohaterem jest osoba opowiadająca, jest ona centralną postacią wypowiedzi, wszystkie wątki jej dotyczą, wokół jego uczuć i przeżyć tworzona jest opowieść.

\section{b) Stopień jasności motywów i intencji}

1. zupełnie nie wiadomo, jakie są cele bohatera i motywy jego postępowania,

2-4. stopnie pośrednie,

5. motywy i intencje bohatera są zdecydowanie jasne i klarowne.

\section{c) Spójność wypowiedzi}

1. wypowiedź jest niespójna, przedstawione w niej informacje nie są ze sobą powiązane,

2-4. stopnie pośrednie,

5. wypowiedź została sformułowana w postaci pełnej i spójnej historii. Można wyraźnie określić wstęp, rozwinięcie i zakończenie (niekoniecznie przedstawione w kolejności chronologicznej). 
Sprawczość i wspólnotowość to dwa główne wymiary ludzkiej egzystencji (Bakan, 1966), a zdaniem McAdamsa (1985) dwie modalności ujawniające się we wszystkich narracjach, w których ludzie opisują swoje doświadczenia. Sprawczość wiąże się z dążeniem do indywiduacji i separacji poprzez realizację własnych celów, osiągnięć, dominacji i samorozwoju, a wspólnotowość z dążeniem do integracji z innymi poprzez troskę o nich, pogłębianiem relacji z innymi ludźmi i współpracy, koncentracją na innych, intymnością i afiliacją. W badaniu zastosowaliśmy system kodowania nasilenia motywów sprawczości i wspólnotowości opracowany przez McAdamsa i opublikowany na stronie internetowej Foley Center for the Study of Lives (2008). Zgodnie z ta metodą analiza polega na poszukiwaniu w treści narracji wypowiedzi świadczących o tym, że dany motyw pełni funkcję podstawowej ramy tematycznej nadawania znaczenia doświadczeniu, którego dotyczy narracja.

\section{Kwestionariusze:}

Kwestionariusz BHI-R służy do pomiaru poziomu nadziei podstawowej, rozumianej jako przekonanie o dwóch cechach świata: o tym, że świat ma obiektywny porządek i sens, oraz o tym, że świat jest w ostateczności ludziom przychylny (Trzebiński i Zięba, 2003, 2004). BHI-R jest narzędziem samoopisowym składającym się z 16 stwierdzeń diagnostycznych, takich jak: Świat jest sprawiedliwy i każdy otrzyma prędzej czy później to, na co zasłużyl; Nasze wysiłki i starania mają sens, bo nie jesteśmy zdani na ślepy los; Swiat jest w gruncie rzeczy dobry, nawet jeśli jest nam źle. Badany określa, w jakim stopniu zgadza się z poszczególnymi stwierdzeniami, wybierając każdorazowo jedną z odpowiedzi na 5-stopniowej skali od „zdecydowanie nie zgadzam się" do "zdecydowanie zgadzam się". Analiza właściwości psychometrycznych skali przeprowadzona w grupie 1985 osób wskazuje na jej wysoką rzetelność i stabilność w czasie, a także satysfakcjonującą trafność teoretyczną (Zięba, 2010).

Kwestionariusz Nadziei na Sukces KNS to polska adaptacja Adult Dispositional Hope Scale (Snyder i in., 1991) w opracowaniu Łaguny, Trzebińskiego i Zięby (2005). Kwestionariusz KNS mierzy pozytywny stan motywacyjny człowieka oparty na dwóch przekonaniach: o posiadaniu silnej woli i o umiejętności znajdowania rozwiązań. Kwestionariusz składa się z 12 stwierdzeń. Cztery z nich mierzą przekonanie o posiadaniu silnej woli, np.: Energicznie realizuje moje zamierzenia; kolejne cztery służą do pomiaru przekonania o umiejętności znajdowania rozwiązań, np. Potrafię rozważyć wiele możliwości dochodzenia do rzeczy, na których mi najbardziej zależy. Kwestionariusz zawiera 8-stopniową skalę odpowiedzi, za pomocą której osoba badana ocenia stopień, w jakim podane stwierdzenia ją opisują. Kwestionariusz odznacza się satysfakcjonującymi właściwościami psychometrycznymi (Łaguna, Trzebiński i Zięba, 2005).

Skala Samooceny SES Rosenberga w polskiej adaptacji Dzwonkowskiej, Łachowicz-Tabaczek i Łaguny (2008) składa się z 10 twierdzeń (np. Uważam, że jestem osobą wartościową przynajmniej w takim samym stopniu, co inni) 
mierzonych na 4-stopniowej skali. Rzetelność skali oceniona za pomocą alfy Cronbacha wynosi 0,82 (Łaguna, Lachowicz-Tabaczek i Dzwonkowska, 2007).

Kwestionariusz Refleksyjności LMS to opracowana przez Mateusza Zatorskiego eksperymentalna wersja Langer Mindfulnes Scale, narzędzia mierzącego indywidualne różnice $\mathrm{w}$ zakresie refleksyjności traktowanej jako styl poznawczy (Langer, 2004). Kwestionariusz składa się z 21 twierdzeń. Osoba badana ocenia na 7-stopniowej skali typu Likerta, w jakim stopniu każde z określeń opisuje jej formę funkcjonowania poznawczego. Kwestionariusz oprócz wyniku ogólnego pozwala określić poziom czterech składowych refleksyjności: aktywności poznawczej (novelty seeking), twórczości (novelty producing), giętkości (flexibility) i zaangażowania (engagement). W badaniach walidacyjnych prowadzonych w grupie 432 osób stwierdzono satysfakcjonujący poziom rzetelności skali (Zatorski, 2011).

Kwestionariusz Stress-Related Growth Scale służący do pomiaru wzrostu potraumatycznego to polska adaptacja narzędzia Park, Cohena i Murcha (1996) autorstwa Czarneckiej-van Luijken i Zięby (2010). W niniejszym badaniu kwestionariusz zawierał zmodyfikowaną ze względu na specyfikę grupy instrukcję, która zaczynała się od zdania: "Zastanów się, jakie konsekwencje dla Ciebie i Twojego życia przyniósł przeszczep". Następnie osoba badana na 3-stopniowej skali określała, na ile zgadza się z każdym z 50 stwierdzeń, np.: Przemyślalem na nowo, jak chce żyć; Dowiedziałem się, że istnieje więcej ludzi, którym na mnie zależy, niż mi się wydawało. W badaniach walidacyjnych $w$ grupie 356 osób kwestionariusz uzyskał wysoką rzetelność $\alpha=0,95$ (Czarnecka-van Luijken i Zięba, 2010).

\section{Wyniki}

W pierwszym etapie analizy wyników uzyskanych w badaniu dokonaliśmy analiz wskaźników wyodrębnionych w rezultacie kodowania narracji osób badanych, które ujęte zostały na skalach ilościowych, a także danych uzyskanych w pomiarze kwestionariuszowym.

Średni poziom samooceny w badanej grupie odpowiadał 5. stenowi, a nadziei podstawowej i nadziei na sukces 6. stenowi (dla refleksyjności oraz wskaźników narracyjnych nie ma polskich norm populacyjnych), a zatem były to wyniki przeciętne. Średni poziom wzrostu potraumatycznego był zaś prawdopodobnie wyższy niż w innych grupach, w których stosowano polską wersję SRGS, i średni wynik wynosił w nich od 99 do 105 (Czarnecka-van Luijken i Zięba, 2010).

Wyniki analizy korelacji wskazują na dużą współzmienność nadziei podstawowej, nadziei na sukces i samooceny oraz refleksyjności, jednak spośród tych zmiennych tylko nadzieja podstawowa okazała się istotnie związana z poziomem wzrostu potraumatycznego. Okazało się również, że im wyższy był poziom narracyjności opowiadań uczestników badania, tym wyższy był poziom 
Tabela 1. Korelacje r-Pearsona / rho Spearmana dla wzrostu potraumatycznego, narracyjności, nasilenia motywów sprawczości i wspólnotowości, nadziei podstawowe, nadziei na sukces, samooceny oraz refleksyjności

\begin{tabular}{|c|c|c|c|c|c|c|c|c|c|}
\hline & $\mathbf{M}$ & SD & 1 & 2 & 3 & 4 & 5 & 6 & 7 \\
\hline $\begin{array}{l}\text { 1. Wzrost } \\
\text { potraumatyczny }\end{array}$ & 115,63 & 22,10 & - & & & & & & \\
\hline 2. Narracyjność & 2,69 & 1,06 & $0,41^{*}$ & - & & & & & \\
\hline 3. Motyw sprawczości & 1,47 & 0,84 & 0,07 & 0,21 & - & & & & \\
\hline $\begin{array}{l}\text { 4. Motyw } \\
\text { wspólnotowości }\end{array}$ & 2,72 & 0,68 & 0,27 & $-0,02$ & 0,32 & - & & & \\
\hline $\begin{array}{l}\text { 5. Nadzieja } \\
\text { podstawowa }\end{array}$ & 60,62 & 9,03 & $0,43^{*}$ & 0,01 & $-0,04$ & 0,14 & - & & \\
\hline $\begin{array}{l}\text { 6. Nadzieja } \\
\text { na sukces }\end{array}$ & 50,23 & 8,49 & 0,25 & 0,15 & 0,15 & $0,39^{*}$ & $0,56^{* *}$ & 一 & \\
\hline 7. Samoocena & 29,57 & 4,06 & 0,15 & $-0,03$ & $-0,01$ & 0,20 & $0,51^{* *}$ & $0,47^{* *}$ & - \\
\hline 8. Refleksyjność & 101,91 & 15,73 & 0,15 & 0,05 & 0,13 & 0.26 & $0,46^{* *}$ & $0,71^{* *}$ & $0,37^{*}$ \\
\hline
\end{tabular}

* Korelacja jest istotna na poziomie $p<0,05$ (dwustronnie);

** Korelacja jest istotna na poziomie $p<0,01$ (dwustronnie)

Korelacje rho Spearmana obliczono dla par zmiennych wśród których był motyw wspólnotowości lub motyw sprawczości, gdyż rozkład tych zmiennych nie spełniał założenia o normalności. Dla pozostałych zmiennych obliczono korelacje $r$-Pearsona. 
wzrostu potraumatycznego mierzony 10-12 miesięcy później. Narracyjność nie wiązała się zaś $\mathrm{w}$ żaden sposób z poziomem pozostałych mierzonych w I etapie badania zmiennych.

W celu określenia, czy i w jakim stopniu można przewidywać wzrost potraumatyczny na podstawie poziomu nadziei podstawowej oraz narracyjności opowiadań o ważnych wydarzeniach, przeprowadziliśmy analizę regresji liniowej, której wyniki prezentuje Tabela 2.

Tabela 2. Analiza regresji liniowej dla nadziei podstawowej oraz narracyjności jako predyktorów wzrostu potraumatycznego po uplywie 10-12 miesięcy

\begin{tabular}{|l|l|l|l|}
\hline & \multicolumn{1}{|c|}{ Beta } & \multicolumn{1}{c|}{$\boldsymbol{P}$} & \multicolumn{1}{c|}{$\boldsymbol{P}$} \\
\hline Nadzieja podstawowa (I pomiar) & 0,41 & 2,71 & 0,011 \\
\hline Narracyjność (I pomiar) & 0,40 & 2,68 & 0,012 \\
\hline
\end{tabular}

Model regresji wyjaśnia $29,7 \%$ zmienności wzrostu potraumatycznego (skorygowane R-kwadrat wynosi 0,297) i jest dobrze dopasowany do danych: $F(2,31)=7,33 ; p=0,003$. Model obejmujący nadzieję podstawową i narracyjność pozwala istotnie lepiej niż każda z tỵch zmiennych pojedynczo przewidywać poziom wzrostu potraumatycznego.

Analizy jakościowe, których celem było wyodrębnienie formalnych i treściowych cech narracji pacjentów charakteryzujących się stosukowo wysokim poziomem wzrostu potraumatycznego, nie przyniosły istotnych rezultatów. Nie udało nam się w badanej próbie odkryć żadnych powtarzających się interindywidualnie charakterystyk narracji, które wiązałyby się z poziomem wzrostu potraumatycznego. Zróżnicowanie sytuacyjne i indywidualne w badanej grupie było tak duże, że choć w wyniku przeprowadzenia wielostopniowej analizy i interpretacji hermeneutycznej zebranego materiału uzyskaliśmy wiele interesujących obserwacji na poziomie pojedynczych osób, to ze względu na to zróżnicowanie trudno było o uogólnienie i syntezę danych.

\section{Dyskusja wyników}

Wyniki uzyskane w badaniu są w większości zgodne z oczekiwaniami i wskazują na pozytywny związek nadziei podstawowej oraz narracyjnej strukturalizacji doświadczenia ze wzrostem potraumatycznym. Uzyskane wyniki potwierdzają rezultaty wcześniejszych prac, jednak wnioski płynące z badania, w którym pomiar zmiennych wyjaśniających poprzedzał o 10-12 miesięcy pomiar wzrostu potraumatycznego, mogą być uważane za bardziej prawomocne.

Podobnie jak w wielu poprzednich badaniach, nadzieja podstawowa okazała się lepszym predyktorem wzrostu potraumatycznego niż nadzieja na sukces 
(Trzebiński i Zięba, 2012; Zięba, Czarnecka-van Luijken i Wawrzyniak, 2010), a także lepszym niż samoocena. Przekonanie o sensowności i przychylności świata może w sytuacji ważnego wydarzenia życiowego, jakim jest przeszczep organu, sprzyjać formułowaniu bardziej pozytywnych oczekiwań wobec przyszłości, co z kolei może pełnić pozytywną rolę w procesie wzrostu potraumatycznego (Tedeschi i Calhoun, 2012). Pozytywne przekonania na temat samego siebie (samoocena) i umiejętności radzenia sobie $z$ trudnościami (nadzieja na sukces), których poziom w badanej próbie nie pozwalał przewidywać wzrostu potraumatycznego, pelnią odmienną niż nadzieja podstawowa rolę w procesie adaptacji i mogą sprzyjać większej satysfakcji z życia, której poziom nie był w badaniu kontrolowany.

Ważne praktycznie znaczenie wydaje się mieć uzyskany w badaniu wynik, wskazujący na pozytywną rolę narracyjnego ujmowania doświadczenia. Wynik ten jest zbieżny z płynącymi z doświadczeń klinicznych propozycjami Calhouna i Tedeschiego (2013), wskazującymi na ważną rolę narracji w interwencji psychologicznej, wspierającej proces wzrostu potraumatycznego. W prezentowanym badaniu narracyjność traktowana była jako indywidualna właściwość czy też predyspozycja osób badanych do tworzenia reprezentacji poznawczych epizodów ze swojego życia w formie narracji. Zgodnie z podejściem McAdamsa (1993, 2013) uważamy, że ludzie znacząco różnią się między sobą ze względu na tendencję do narracyjnego ujmowania doświadczeń. Osoby, które opowiadają o swoich dawnych przeżyciach, nadając tym opowieściom strukturę narracji, prawdopodobnie częściej używać będą tej struktury do porządkowania aktualnych doświadczeń czy też formułowania oczekiwań wobec przyszłości. Konstruowanie reprezentacji poznawczej wydarzenia w formie narracji jest jednỵm z mechanizmów prowadzących do wzrostu potraumatycznego (Neimeeyer, 2006; Pals, 2006; Smyth, True i Suoto, 2001). Zaprezentowane powyżej wyniki dotyczące pozytywnego związku narracyjności i wzrostu potraumatycznego mogą być zachętą do przeprowadzenia badań, w których obserwowany będzie wplyw kompetencji narracyjnej (Stemplewska-Żakowicz i in., 2006) na konstruowanie w formie narracji reprezentacji poznawczej konkretnego traumatycznego doświadczenia, a w dalszej kolejności - wpływu narracyjnej formy ujmowania doświadczenia na będący jego odległym następstwem wzrost potraumatyczny.

Należy zauważyć pewne ograniczenia przyjętej metody. Pierwszy pomiar przeprowadzony został już po przeszczepie, a zatem w trakcie adaptacji do nowej sytuacji, a nie przed wydarzeniem uruchamiającym proces wzrostu potraumatycznego. W przyszłych badaniach warto podjąć próbę wcześniejszego pomiaru zmiennych wyjaśniających, podobnie jak zostało to uczynione w badaniu Laupacisa i wspótpracowników (1996). Wśród innych ograniczeń badania warto wymienić stosunkowo mało liczną grupę pacjentów, co podważa możliwość uogólniania wyników. Również zastosowane w badaniu metody kwestionariuszowe wiążą się z pewnymi ograniczeniami, szczególnie w odniesieniu do pomiaru wzrostu potraumatycznego. Pomiar kwestionariuszowy ma w tym 
kontekście istotną cechę - sprowadza zakres zmian w fundamentalnych przekonaniach nt. samego siebie i świata do konkretnych obszarów czy kategorii. Ludzie odpowiadają na pytania o to, co w wyniku wydarzenia traumatycznego zmieniło się w określonych sferach - percepcji siebie, relacjach interpersonalnych i w filozofii życiowej. Możliwe jest jednak, że ludzie doświadczają pozytywnych zmian w globalnym poziomie sensu i znaczenia życia, ale w innych niż mierzone w standardowych kwestionariuszach obszarach, np. hierarchii i treści celów życiowych, przekonań na różne tematy, tożsamości (Park i Lechner, 2006). W przyszłych badaniach warto będzie uzupełnić pomiar wzrostu potraumatycznego o metody jakościowe (wywiad psychologiczny), pozwalające na dotarcie do indywidualnych znaczeń nadawanych doświadczeniu.

\section{Bibliografia}

Bakan, D. (1966). The duality of human existence: Isolation and communion in Western man. Boston: Beacon Press.

Bruner, J. S. (1986). Actual minds, possible worlds. Cambridge, MA: Harvard University Press,

Bruner, J. S. (1991). The narrative construction of reality. Critical Inquiry, 18, 1-21.

Budziszewska M. (w druku). WYwiad biograficzny Dana McAdamsa - adaptacja polska i niektóre możliwości interpretacyjne. Przegląd Psychologiczny.

Calhoun, L.G. i Tedeschi, R. G. (2006). The foundations of posttraumatic growth: an expended framework (s. 3-23). W: L.G. Calhoun i R.G. Tedeshi (red.), Handbook of posttraumatic growth: research and practice. New York: Lawrence Erlbaum Associates.

Calhoun, L. G. i Tedeschi, R. G. (2013). Posttraumatic growth in clinical practice. New York, NY US: Routledge/Taylor \& Francis Group.

Czarnecka-van Luijken, J. i Zięba, M. (2010). Preliminary report on our findings from research we have conducted as the Polish adaptation of Stress Related Growth Scale. Warszawa: nieopublikowany manuskrypt.

Dzwonkowska, I., Lachowicz-Tabaczek, K., i Łaguna, M. (2008). Samoocena i jej pomiar. Skala samooceny SES M. Rosenberga. Warszawa: Pracownia Testów Psychologicznych.

Gergen, K. J. i Gergen, M. M. (1986). Narrative Form and the Construction of Psychology Science. W: T.R. Sarbin, (red.), Narrative Psychology. The Storied Nature of Human Conduct (s. 22-44). Westport, Connecticut: Praeger Press.

Gum, A. i Snyder, C. R. (2002). Coping with terminal illness: The role of hopeful thinking. Journal of Palliative Medicine, 5(6), 883-894.

Heszen, I. i Sęk, H. (2007). Psychologia zdrowia. Warszawa: WYd. Naukowe PWN.

Janoff-Bulman, R. (1992). Shattered assumption: towards a new psychology of trauma. New York: Free Press.

Janoff-Bulman, R. (2006). Schema-change perspectives on posttraumatic growth. W: L.G. Calhoun i R.G. Tedeshi (red.), Handbook of posttraumatic growth: research and practice (s. 81-99). New York: Lawrence Erlbaum Associates.

Langer, E. J. (1989). Mindfulness. Reading, MA: Addison-Wesley.

Langer, E. J. (2004). Langer mindfulness scale user guide and technical manual. Covenington, IL: IDS.

Linley, P. A. i Joseph, S. (2004). Positive change following the trauma and adversity: A review. Journal of Traumatic Stress, 17, 11-21. 
Łaguna, M., Lachowicz-Tabaczek, K. i Dzwonkowska, I. (2007). Skala samooceny SES Morrisa Rosenberga - polska adaptacja metody. Psychologia Spoteczna, 2, 164-176.

Łaguna, M., Trzebiński, J. i Zięba, M. (2005). Kwestionariusz Nadziei na Sukces. Warszawa: Pracownia Testów Psychologicznych PTP.

McAdams, D. P. (1985). Power, intimacy, and the life story: Personological inquiries into identity. New York: Guilford Press.

McAdams, D. P. (1993). The stories we live by: Personal myths and the making of the self. New York, NY US: William Morrow \& Co.

McAdams, D.P. (2001). The Psychology of Life Stories. Review of General Psychology, 5(2), 100-122.

McAdams, D. P. (2013). How actors, agents, and authors find meaning in life. W: K.D. Markman, T. Proulx, M.J. Lindberg (red.), The psychology of meaning (s. 171-190). Washington, DC US: American Psychological Association.

Mischel, W. i Shoda, Y. (2008). Toward a unified theory of personality: Integrating dispositions and processing dynamics within the cognitive-affective processing system. W: O.P. John, R.W. Robins i L.A. Pervin, (red.), Handbook of personality: Theory and research (3rd ed.) (s. 208-241). New York, NY US: Guilford Press.

Neimeyer, R. A. (2006). Re-storying loss: fostering growth in the posttraumatic narrative. W: L.G. Calhoun i R.G. Tedeshi (red.), Handbook of posttraumatic growth: research and practice (s. 68-80). New York; Lawrence Erlbaum Associates.

Ogińska-Bulik, N. (2013). Pozytywne skutki wydarzeń traumatycznych, czyli kiedy łzy zamieniaja się w perly. Warszawa: Difin.

Ogińska-Bulik, N., i Juczyński, Z. (2008). Osobowość: stres a zdrowie. Difin.

Ogińska-Bulik, N., i Juczyński, Z. (2010). Rozwój potraumatyczny - charakterystyka i pomiar. Psychiatria, 7(4), 129-128.

Payne, A. J., Joseph. S. i Tudway, J. (2007). Assimilation and accommodation processes following traumatic experiences. Journal of Loss and Trauma, 12(1), 75-91.

Pals, J. i McAdams, D. (2004). The Transformed Self: A Narrative Understanding of Posttraumatic Growth. Psychological Inquiry, 15(1), 65-69

Pals, J. L. (2006). Narrative identity processing of difficult life experiences: Pathways of personality development and positive selftransformation in adulthood. Journal of Personality, 74, 1079-1110.

Park, C. L. (2009). Overview of Theoretical Perspectives. W: C.L. Park, S.C. Lechner, M.H. Antoni, i A.L. Stanton, (red.). Medical Illness and Positive Life Change (s. 11-30). Washington, DC: APA.

Park, C. L., Cohen, L. i Murch, R. (1996). Assessment and prediction of stress-related growth. Journal of Personality, 64, 71-107.

Park, C. L. i Lechner, S. (2006). Measurement issues in assessing growth following stressful life experiences. W: L.G. Calhoun i R.G. Tedeshi (red.). Handbook of posttraumatic growth: research and practice (s. 47-67). New York: Lawrence Erlbaum Associates.

Pennebaker, J. W. i Seagal, J. D. (1999). Forming a Story: The Health Benefits of Narrative. Journal of Clinical Psychology, 55(10), 1243-1254.

Smyth, J. M., True N., Souto J. (2001). Effects of writing about traumatic experiences: the necessity for narrative structuring. Journal of Social and Glinical Psychology, 20, 161-172.

Snyder C. R, Cheavens J., Michael S. T. (1999). Hoping. W: C.R. Snyder (red.). Coping: The Psychology of What Works (s. 205-231). Oxford University Press: New York.

Snyder, C. R., Harris, Ch., Anderson, J. R., Holleran, S. A., Irving, L. M., Sigmon, S. T., Yoshinobu, L., Gibb, J., Langelle, Ch. i Harney, P. (1991). The will and ways: development and validation of an individual-difference measure of hope. Journal of Personality and Social Psychology, $60(4), 570-585$.

Snyder, C. R., Sympson, S. C., Michael, S. T., Cheavens, J. (2000). Optimism and hope constructs: variations on a positive expectancy theme. W: E.C. Chang (red.), Optimism and pessimism: Implications for theory, research and practice (s. 101-123). Washington, DC: American Psychological Association. 
Stanton, A. L, Bower, J. E. i Low, C. A. (2006). Posttraumatic growth after cancer. W: L.G. Calhoun \& R.G. Tedeshi (Red.), Handbook of posttraumatic growth: research and practice (s. 138-175). New York: Lawrence Erlbaum Associates.

Stanton, A. L., Danoff-Burg, S. i Huggins M. (2002). The first year after breast cancer diagnosis: hope and coping strategies as predictors of adjustment. Psycho-Oncology, 11(2), 93-103.

Stemplewska-Żakowicz, K., Piotrowska, M., Szewczyk, A. i Wawrzeniecki, D. (2006). Kompetencja narracyjna. Psychologia Jakości Zycia 5(2), 161-188.

Tedeschi, R.G. i Calhoun, L.G. (2004). Posttraumatic growth: Conceptual Foundations and Empirical Evidence. Psychological Inquiry, 15(1), 1-18.

Tedeschi, R. G. i Calhoun, L. G. (2012). Pathways to personal transformation: Theoretical and empirical developments. W: P.P. Wong (red.), The human quest for meaning: Theories, research, and applications (2nd ed.), (s. 559-572). New York, NY US: Routledge/Taylor \& Francis Group.

Tobiasz-Adamczyk B. (1998). Wybrane elementy socjologii zdrowia i choroby. Kraków: Wydawnictwo UJ.

Tennen, H. i Affleck, G. (1998). Personality and transformation in face of adversity. W: R.G. Tedeshi, C. L. Park i L.G. Calhoun (red.), Posttraumatic growth: positive changes in aftermath of crisis (s. 65-98). Mahwah, New Jersey: Lawrence Erlbaum Associates.

Trzebiński, J. (2002). Narracyjne konstruowanie rzeczywistości. W: J. Trzebiński (red.). Narracja jako sposób rozumienia świata (s. 17-42), Gdańsk: GWP.

Trzebiński, J. i Zięba, M. (2003). Kwestionariusz Nadziei Podstawowej - BHI-12. Warszawa: Pracownia Testów Psychologicznych PTP.

Trzebiński, J., Zięba, M. (2004). Basic hope as a world-view: an outline of a concept. Polish Psychological Bulletin, 2, 171-182.

Trzebiński, J. i Zięba, M. (2012). Basic trust and posttraumatic growth in oncological patients. Journal of Loss and Trauma, 18(3), 195-209.

Zatorski, M. (2011). Wpływ refleksyjności i narracyjnego rozumienia zdarzeń na poziom zapamiętywania i kreatywność w myśleniu o nich. Nieopublikowana praca doktorska, Szkoła Wyższa Psychologii Społecznej.

Zięba, M., Czarnecka-van Luijken i Wawrzyniak, M. (2010). Nadzieja podstawowa i wzrost potraumatyczny, Studia Psychologiczne, t. 49, z. 1, 109-121.

Zięba, M. (2010). Właściwości psychometryczne kwestionariusza BHI-R. Wstępny raport z badań walidacyjnych. Pobrane z: http://nadziejapodstawowa.pl 


\section{Mariusz Zieba}

Institute of Psychology, University of Social Sciences and Humanities, Faculty in Poznan

Mateusz Zatorski

Department of Psychology, University of Social Sciences and Humanities, Warsaw

\section{Narratives and basic trust as moderators of posttraumatic growth after kidney transplantation}

Chronic renal failure and kidney transplant surgery is a life event involving the many serious consequences, significantly affecting health-related quality of life, but also may lead to posttraumatic growth. In this paper we present the study of 51 patients after kidney transplantation. In the first stage of the study, 4 weeks after transplantation, were measured the level of basic trust (BHI-R), hope (KNS), self-esteem (SES) and mindfulness (LMS), and then carried out narrative interview. 10-12 months later was measured posttraumatic growth (SRGS). The results of the study indicate positive role of basic trust in posttraumatic growth year after kidney transplantation. Also important is the tendency to construct stories about their experiences in narrative form.

Key words: posttraumatic growth, basic trust, narrative, kidney transplantation, health psychology 